\title{
Because you're worth it? Determinants of Vice Chancellor pay in the UK
}

Article

Accepted Version

Walker, J., Greve, P., Wood, G. and Miskell, P. (2019) Because you're worth it? Determinants of Vice Chancellor pay in the UK. Industrial Relations Journal, 50 (5-6). pp. 450-467. ISSN 0019-8692 doi: https://doi.org/10.1111/irj.12265 Available at https://centaur.reading.ac.uk/85460/

It is advisable to refer to the publisher's version if you intend to cite from the work. See Guidance on citing.

To link to this article DOI: http://dx.doi.org/10.1111/irj.12265

Publisher: Wiley

All outputs in CentAUR are protected by Intellectual Property Rights law, including copyright law. Copyright and IPR is retained by the creators or other copyright holders. Terms and conditions for use of this material are defined in the End User Agreement.

\section{www.reading.ac.uk/centaur}

\section{CentAUR}

Central Archive at the University of Reading

Reading's research outputs online 


\title{
Because you're worth it? Determinants of Vice Chancellor pay in the UK
}

\author{
James Walker*, Peder Greve*, Geoff Wood** and Peter Miskell* \\ International Business and Strategy, Henley Business School, University of Reading*, \\ Ivy Business School, Western University**
}

\begin{abstract}
Wage inequality has increased across most developed nations; this has been manifested in a wide range of organizations and sectors, with implications for well-being and sustainability; within UK universities this has become increasingly visible. There is increasing pressure on universities to deliver social and economic impact in an increasingly market and metric driven environment. In the UK context, increasing financial pressure has led to both an escalation of student fees, and constrained wage growth for faculty. In contrast, most Vice-Chancellors have secured substantive pay packages raising concerns that regulatory failures may be contributing to the rise. We show that V-Cs use their internal power within organisations to extract a disproportionate amount of the value created by the institution. However, we encountered much diversity according to the quality of governance, highlighting the extent to which not only contextual, but also internal dynamics drive wage inequality.
\end{abstract}

Keywords Pay, Governance, Metrics, Performance, Vice-Chancellors

\section{INTRODUCTION}

A key theme within the current literature on industrial relations is of rising wage inequality both within and between contexts (Ackers, 2016; Stockhammer, 2017). Although this trend is encountered within most developing economies, it is a very uneven one, reflecting both contextual and sub-contextual dynamics (Stockhammer, 2017). In the UK Higher Education context, the gap between senior managers - above all, Vice Chancellors - and the rank and file, has become increasingly visible. This raises issues of staff well-being, sustainability, and whether indeed, there is any justification for a divergence in the relative allocation of value (Edwards, 2015; Ackers, 2016). As Guest (2011) notes, one of the core dilemmas of HRM remains the elusiveness of tracing links between HRM systems and performance (c.f. 
Boselie et al. 2005). Yet, the 2008- financial crisis highlighted the risks posed by inappropriate reward systems, and the need to find better ways of incentivising senior managers. Within UK universities have come under increasing attack both in the popular media and by politicians inter alia for a failure to be relevant to the needs of the 'real world', a perceived liberal bias, and because they allegedly provide poor value for money for taxpayers and students (Daily Mail 2017a; 2017b). As these claims have escalated, so have threats by the UK government both to place universities under closer regulatory scrutiny and provide more opportunities for private competitors as a countervailing pressure (ITV 2017; THES, 2017b). Within the UK, the issue of Vice Chancellors' (V-C) salaries has been added to the mix: critics have charged that they are pseudo-public servants with few opportunities to really change the institutions they run, they are inattentive to the needs of students as customers, and yet are able to extract large pay packages relative to their colleagues on the 'coal-face' (Guardian 2018; ITV 2017). It has been argued that this represents a regulatory failure, making a strong case for external corporate governance reform (c.f. ITV 2017; Telegraph 2017). There is a considerable literature exploring the pay and performance of organisational heads (Shaw and Gupta, 2015), and a growing body of work exploring the remuneration of university heads worldwide (e.g. Cornell, 2004; Clements and Izan, 2008; Tarbert et al., 2008; Essaji and Horton, 2010; Bachin and Reilly, 2017; Ross, 2019). This study departs from this literature in explores the extent to which VC pay whether internal corporate governance mechanisms can make a difference drawing upon a variety of data sources covering the $2013 / 14$ to $2016 / 17$ period where information on governance can obtained.

Our results show that V-C pay is at least partially determined by internal governance mechanisms, performance metrics and individual V-C characteristics. In other words, rather 
than a systemic failing, some universities seem much better at managing VC pay than others. We explore the implications of these findings for theory and practice.

\section{THE ROLE OF THE UNIVERSITY AND THE UK CONTEXT}

There are two broad ways in which the university may be theorised. The first is that effective research operates in a 'republic of science', which should be removed from commercial and social pressures that dominate in other parts of society (Polanyi, 2000). According to this view, it can be argued that an independent intellectual class having the institutional space and support to generate well-crafted scholarly ideas is a good in its own right, enriching public and social life, and indeed, forming an integral part of being civilised (Oakeshott, 2004). The second is one that ties academic research - and indeed, university teaching - to immediate and directly visible economic and social development. This view that often equates research and universities as potential 'engines of growth'; and posits that universities should concentrate on unlocking such economic potential (Perkmann et al., 2013).

Despite some inroads by private-for-profits (and a small number of private nonprofits) the UK university system remains dominated by institutions that historically enjoyed both statutory recognition and 'self-governing autonomy'. The latter, whilst not-for-profit and providing a broad public service, are neither purely charitable or purely statist (Moodie and Eustace 2011). In terms of charters and statutes issued by the Privy Council, internal governance structures centring on Courts, Councils and Senates were set up; in 1946 the bulk of university financing was taken over by the state, when previously their role was somewhat akin to charities. The 1946 changes opened the way for affordable mass education, but diminished the relative influence of lay Courts and Councils, supplanting their historic role in raising funding. It also empowered senates, bodies dominated by senior academics, however, the role of the V-C remained closely circumscribed, with decision making now firmly resting 
in the hands of an 'oligarchy' of senior academics (Shattock, 2017). In the 1980s, radical changes to the funding environment led to the creation of funding councils as direct instruments of government, rather than autonomous policy organs; budget cutbacks forced VCs to take closer direct control over trying to allocate diminished funding. The 1985 Jarrett Report cast V-Cs as Chief Executive Officers (CEOs), and encouraged smaller and more assertive councils; on gaining university status in 1992 (Jarrett, 1985), the former polytechnics were restructured to concentrate power around the V-C (Shattock, 2017). The 1997 Dearing and 2003 Lambert report resulted in the streamlining of Senates and Councils, ultimately diluting their effectiveness (Shattock, 2017).

Perhaps the greatest transformation in university governance has been the transfer of decision-making powers over such policies to chief executive like V-Cs, and small teams and to 'manager academics' (Deem et al. 2007): inner cabinets answerable to senates have become Senior Management Teams, administrators have become managers. Evidence for this transformation can be found in a systematic shift to top-down reorganisations of academic decision-making structures. In two successive studies conducted over the 1993-2002 and 2002-2007 period found that 74 per cent of institutions examined in the first and 65 per cent in the second had been subjected to quite fundamental restructuring involving reducing and merging faculties and departments, the creation of devolved colleges or schools and the establishment of new senior officer posts to be filled through public advertisement from outside the university rather than by election from within (Hogan, 2012). Between 19941995 and 2008-2009 the proportion of university expenditure on university administration and central services grew significantly at the expense of expenditure on academic departments (Hogan, 2011).

The alignment of evaluation metrics, most notably, the Research Excellence Framework (REF) (Lee, 2006), and potentially, the National Student Survey, and revenue 
flows produced significant changes in university funding (Shattock, 2017). More specifically, the Higher Education Act 2004 led to the imposition of fees capped at $£ 3,000$ that were adjusted to $£ 3,225$ a year to take account of inflation by 2009 . However, the abolition of the cap was controversially proposed by the Brown Review in 2010 . While the Government did not implement the Brown recommendations it did extend the fee cap to $£ 9,000$, envisaging that a competitive market would erupt, with institutions competing on the basis of cost or quality. Following a failed judicial review against the fee rise it came in to effect in $2012 .{ }^{1}$ In practice this lead to most universities opting for the maximum allowable fee, and competing on the basis of reputation alone, often backed up by external metrics. Coupled with this has been increased competition for overseas students, again with the market disrupted by government action, in this case in the form of increasingly onerous visa requirements.

\section{INTERNAL AND EXTERNAL CORPORATE GOVERNANCE}

At the heart of their governance is the underlying fact that UK universities are voluntary associations with transient memberships; academics typically move between institutions in their careers, and students study for fixed periods of time (Moodie and Eustace, 2011; Oakeshott, 2004). On the one hand, this transience makes it easier to reconcile competing interest groupings, to sustain and develop a hereditary purpose, and makes for a great deal of resilience (ibid.). On the other hand, this transience makes it easier to bring about fundamental changes in governance; whilst members may resist changes, it is equally likely that the discontented will exit (or simply complete their studies). Finally, although councils may be akin to company boards, their role is, in relative terms, more circumscribed (Moodie and Eustace, 2011).

1 "Tuition fees case: Callum Hurley and Katy Moore lose". BBC News. 2012-02-17. 
Recent criticism of university governance can be divided into two broad categories. Firstly, there is an implicit application of agency theory: this argument suggests that students or external users are principals and their delegated agents, universities, are failing in their duties to them. Examples of this would include criticisms as to a lack of accountability to students as to how their fees are spent and a similar lack of "real world impact" that is failing research users (Martin 2011). On the one hand, there is little in the formal governance mechanisms of universities to suggest that students or research users are sole or combined principals; on the other hand, this view is widely prevalent, and arguably is likely to interpenetrate future formal or informal governance mechanisms.

Secondly, it has been argued (sometimes by the same proponents of the agency view of universities) that students are consumers, and that the role of the government should be that of a champion and protector of consumer rights (Daily Mail 2017a). A strong emphasis is placed on the need to ensure that students get value for money and that academic staff orientate themselves to delivering optimal customer service (Woodall et al. 2014). Again, it is argued that companies or other users soften get poor value for money given the scale of investment in research (THES, 2017a).

In both these instances, V-C pay has been drawn into the debate: it has been depicted as yet another example of agency failing (Daily Mail 2017a), or of a lack of prioritization of the needs of customers (Daily Mail 2017b). What all these criticisms have in common is that it is seen that there are sector wide structural problems which reflect failings in external governance, and that only tighter regulation, and/or the nurturing and support of private-for profit competitors, can correct the failings. A championing of the interests of third parties in part reflects the effects of a decline in state funding: by moving to a system where students are a key financial contributor to the sector it is no longer credible for the government to 
present itself as either the principal or the main customer of university services, and hence, present itself as looking after those who are to justify constant interventions.

If universities are demonstrably incapable of devising or operating sound internal governance the case for more robust external governance becomes stronger (THES, 2017b). However, if internal governance mechanisms can and do make a difference across the sector, then the case for external regulatory reform becomes less clear. Rather, two alternative arguments come into play. The first is the managing complexity argument (Oswald, 2017). Universities are large and complex organisations, and given the decline of government funding, are something akin to multi-million pound businesses. A complex and turbulent environment requires top managers, who need to be rewarded as such (Stone 2017; Oswald 2017). Again, it has been argued that the need for better customer service requires V-Cs to be better incentivised; those best at it should be rewarded the most (Stone, 2017). More radical critiques argue that excessive V-C pay is simply a product of a surfeit of managerialism (Deem et al. 2007). The effects and effectiveness of internal governance mechanisms in moderating V-C's pay, in ensuring equity, and in aligning it with real performance form the central concern of this article.

\section{HYPOTHESIS DEVELOPMENT}

The review highlights an expansion of funds to universities in a period where greater marketization has occurred, but also that governance structures have not become more dislocated from universities traditional internal structures. With the decline of the senate's institutional influence, decision-making has been increasingly located within remuneration committees populated by members of council and often by V-Cs themselves. Rather than contributing to effective oversight and restraint in the pay-setting process, a body of research suggests that remuneration committees are likely to trigger unintended mechanisms such as 
social comparisons and 'bidding-up' of executive salaries (e.g. Ezzamel and Watson, 1998; Gregory-Smith, 2012).

In the context of this study, rather than attempting to gauge the insider or outsider status of each remuneration committee member, a useful indicator of non-independence would be, as with the case of CEOs in firms, is whether a V-C sits on his/her own remuneration committee (cf. Tosi and Gomez-Mejia 1989). The non-separation of decisionmaking and oversight roles is central to the agency problem that may lead to excessive executive compensation. We therefore expect to find a positive relationship between V-Cs' remuneration committee membership and V-C pay.

H1. Where V-C's are members of Remuneration Committees there will be a positive effect on V-C salary.

Recent corporate governance studies have incorporated remuneration committee size (e.g. Gregory-Smith, 2012; Kent et al., 2016), albeit without much consistent evidence emerging so far. However, the recent study by Kent et al. (2016) provides some impetus for further scrutiny. The authors conclude that a minimum committee size seems necessary in order to engage in effective negotiations on executive pay. Larger committees make it harder to forge consensus around very high rewards, and place pressure on executives to justify their rewards. In the university context, an additional important aspect may be that larger committee size indicates a readiness to include a wider range of stakeholder opinions in the pay-setting process. This is likely to enhance both the quality and integrity of the process. Thus, we propose that the size of remuneration committees is inversely related to V-C pay.

H2. Larger committees will, on average, be able to temper $V$-C remuneration. 
Open information flows align internal and external control, thereby reducing agency problems (e.g. Allegrini and Greco, 2013). On the one hand, greater transparency reduces agency problems by providing more information to shareholders and other significant interest groups. On the other hand, organisations that divulge more information to the market may impose additional costs on top managers, for example by reducing their future bargaining power in the external job market (Hermalin and Weisbach 2012). Powerful managers may seek to recoup some of these costs by demanding higher pay. Thus, even though disclosure may reduce agency problems at the surface-level, it is more likely to be associated with higher executive pay (Kanapathippillai et al., 2017). Hence:

\section{H3. Disclosure levels are positively associated with $V$-C pay}

In order to facilitate a strong link between pay and performance, it is necessary to have clear indicators by which to adjudge success against the mission of the organisation, and second there needs to be a clear governance structure through which agent performance can be adjudged (Shaw and Gupta, 2015). However, Holmström and Milgrom (1991) argue that multiple criteria, with some targets easier to meet than others, could have detrimental effects on the principal's welfare and augmented measurement costs. A major division in the UK university sector is between research intensive and largely teaching orientated institutions, albeit that the outer boundaries between these categories are blurred. In practice, some institutions may prioritise effectiveness in teaching and outreach, and others may place a premium on overall research progress hence:

H4. Pay is positively linked to performance measures that, in turn, will reflect differing institutional missions. 


\section{DATA AND METHOD}

\section{Data}

We derive an annual dataset that cover the 2013/14 to 2016/17 academic years with our sample frame reflecting the availability data relating to governance. We excluded niche institutions composed of specialist arts and agriculture institutions as these had quite different and specialised foci otherwise capturing all other institutions.

\section{Measures}

Dependent variable

Vice Chancellor salary - We use salary data (including pensions) for V-Cs sourced from The Times Higher Education Supplement. We supplement this with information on the pay of Professors, all academic staff and all staff from HESA (Higher Education Statistics Agency).

\section{Independent variables}

Governance structures - A number of characteristics of governance and disclosure are identified by consulting websites of each institution and from information requests to the University College Union. ${ }^{2}$ We draw together information on whether or not the V-C sits on the Remuneration Committee, the number of committee members and the level of disclosure, the latter as follows: Differing degrees of disclosure of the minutes of Remuneration committees in $2013 / 14$ to $2015 / 16$ to information requests of the UCU: $1=$ no minutes of the meetings were provided; $2=$ minutes are provided with redactions; $3=$ full minutes are provided without redactions.

\footnotetext{
${ }^{2}$ Full details and reports are found at https://www.ucu.org.uk/V-Cpay.
} 
Performance - There are a rich set of performance metrics available, some of which are produced annually, while a large-scale research exercise tends to be conducted every four to five years. The time-series measures are extracted for the 2013-14 to 2016-2017 period. A general performance metric we focus upon is the Global University Rankings calculated by The Times Higher Education. This metrics does summarise a set of teaching and research indices. However, $\mathrm{t}$ it provides ranking of only a fraction of institutions, mostly researchintensive ones. To capture perceived teaching 'quality' we supplement this with the National Student Survey, and more specifically, responses to the 'overall satisfaction' question. Institution level citations is based on publication data from Elsevier's Scopus. The overall financial success of institutions is captured in income, expenditure and surplus of each institution with information coming from HESA. We distinguish between three different sources of income: funding body grants; research grants/contracts; and tuition fees. We also capture the enrolment of overseas students, especially for taught postgraduate degrees, given their importance as a revenue stream. It is plausible that $\mathrm{V}-\mathrm{C}$ performance is partially evaluated on overseas student enrolments, given how lucrative they are. We choose two variables that are continuously available in HESA publications to measure such effects: the number of non-home/EU postgraduate and the number of non-Home/EU undergraduates.

We supplement this information with cross-sectional performance measures derived from the results REF (2014) by the Higher Education Funding Council of England (HEFCE). We examine two REF components, and (publication) 'output'. As these data relate to two time periods, rather than being annual measures, we align them to the years where these would be available to assess performance (i.e. REF for 2015-16). ${ }^{3}$

\footnotetext{
${ }^{3}$ HEFCE REF 2014 (http://results.ref.ac.uk) and RAE 2008 (https://www.rae.ac.uk/).
} 
Segmentation and Institutional characteristics - There is considerable organizational variety between the more than 100 universities in the UK. 'Old'/pre-1992 universities tend to have a strong orientation towards research (e.g. Oxford and Cambridge,) and 'new'/post 1992 ones more teaching or industry orientated (e.g. Sheffield Hallam and Gloucester). To capture these differences, we segment between members of the pre- ("old") and post-1992 ("new") universities. We proxy complexity by the number of faculty employed and also capture the proportion of pay to administrative staff relative to total pay (Stone 2017; Oswald 2017).

V-C characteristics - Using Who's Who UK in combination with web searches we derive a list of characteristics that includes: whether the individual came from the private sector, the public sector, from academia, or had recent experience of working both in academic and in the public or private sector, whether the individual had been hired from a pre-92 or post-92 institution, gender, age, country of birth, country located when hired, whether or not the individual had an acting role or a permanent appointment, the institution that the $\mathrm{V}-\mathrm{C}$ graduated from, whether or not the V-C did an undergraduate or postgraduate programme in Oxbridge, the subject area of the V-C (science, social science, arts and humanities), individual academic influence (measured in year field adjusted life time citations taken from Scopus) and whether the individual has obtained a title (such as a CBE or Knighthood).

We incorporate regional dummies to take account of variations in living costs across the country.

\section{Methods}

Our dataset incorporates annual data from $2013 / 14$ to $2016 / 17$. Ideally, we would wish to estimate an econometric model for the determination of V-C pay which will distinguish between the individual's personal attributes, performance metrics, different types of 
institutions and characteristics of the institutions themselves. We undertake a mediation analysis (general treatments of the methods are found in MacKinnon, 2008; Hayes, 2013). Specifically, we assume that one variable $Y$, depends on $X$ and $Z$. Furthermore, $X=f(Z, z 1)$, expressed graphically as follows:

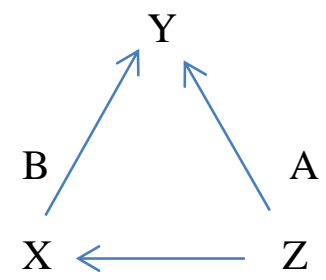

$\mathrm{C}$

We run several regressions: $Y=f(X)$ we estimate the total effect of $X$ on $Y . Y=f(Z)$ we estimate the total effect of $Z$ on $Y . Y=f(X, Z)$ we estimate the direct effect of $X$ on $Y$, once we controlled for $Z$, (arrow $A$ ), and the direct effect of $Z$ on $Y$ once we controlled for $X$ (arrow $B$ ). But, since there is a causal effect from $Z$ to $X$, for example, we would be interested in distinguishing the part of the total effect of $X$ on $Y$ that is due to the indirect effect caused by $Z$ : That is $Z$ affects $X$ that affects $Y$. In this case, we need the estimated effect of $Z$ on $X$ (arrow $C$ ).

In modeling salary we need to account for both how V-C characteristics impact upon the performance of an institution, as well as the direct impact of $\mathrm{V}-\mathrm{C}$ characteristics on salary setting. To account for these, we provided a nested structure first estimating,

$$
X_{i t}=\beta_{0}+\sum_{i=1}^{I} \beta_{i} Z_{i t-1}+v_{t}+\varepsilon_{i t}
$$

Where $Z$ is the one period lagged performance variables of institution $i$, where $X$ are their determinants (in particular VC's individual's personal characteristics). Doing so enables us to extract the indirect impacts of the $Z$ variables. Then we can utilize the predicted values of the performance models in the second stage estimation of remuneration: 


$$
Y_{i t}=\beta_{0}+\sum_{i=1}^{I} \beta_{i} X_{i t}+\sum_{i=1}^{I} \beta_{i} Z_{i t-1}+l_{j}+v_{t}+\varepsilon_{i t}
$$

where $(\log )$ salary is the dependent variable - and the explanatory, $X$ variables, are the direct impacts of $\mathrm{V}-\mathrm{C}$ and institutional characteristics, $\mathrm{Z}$ are a set of performance metrics, $l$ are regional dummies for regions, $j, v_{t}$ are year effects and $\varepsilon_{i t}$ is the error term. We pool the data undertake the analysis using Generalized Least Squares in order to optimize the efficiency of the estimates. ${ }^{4}$

\section{RESULTS}

A priori there are strong reasons to consider that the market is segmented between established research institutions and 'new', typically less research intensive, institutions granted University status as part of a reform of the sector in 1992. Descriptive statistics and pair wise correlations between the dependent and independent main and control variables are given in Table 1 between the "old" (pre-1992) and "new" (post-1992) institutions. ${ }^{5}$ The descriptive data shows that V-C remuneration is about $20 \%$ higher on average in pre-1992 institutions. V-Cs at "old" institutions have more than four times more citations and are more likely to have knighthoods. Some other characteristics are quite similar, but there have been substantive shifts over time. For example, earlier work pointed to $93 \%$ of V-Cs being male. While the proportion of women is still highly unequal the proportion of men has fallen by more than $10 \%$. It is also the case that the proportion of V-Cs who were hired from Deputy $\mathrm{V}-\mathrm{C}$ roles has fallen substantially, while the proportion of new appointments who were V-Cs

\footnotetext{
${ }^{4}$ We did experiment with panel estimation methods. The data did not support random effects estimation. So given many of our variables are time-invariant the approach would greatly reduce the richness of the analysis. Also, we note that, while the key governance findings of the paper were maintained, given our length of the panel is small (less than five years) and fixed effect may biased and inconsistent due to the incidental parameter problem (see Lancaster, 2000 for a review of this literature) we were not confident utilising that methodology and have focused on a pooled regression analysis.

${ }^{5}$ The correlations between explanatory variables are not provided here as due to the extensive nature of the data set, but not particularly high. We also formally tested whether there were differences in means between these two sectors. Not surprisingly, given the magnitude of the differences in the raw means, there were statistical differences in the majority of cases.
} 
previously has risen by more than $20 \%$. Other characteristics have remained relatively stable with the vast majority of appointees, over $90 \%$, being either born or hired in the UK. It is also noteworthy that there are substantial differences in the correlation between the dependent and independent variables between the two types of institution highlighting not examining each separately may mask differences in the drivers of pay within the sector. ${ }^{6}$

\section{$<$ INSERT TABLE $1>$}

Table 2 reports the results of the pooled Generalised Least Squares (GLS) analysis dividing between "old" and "new" institutions where we incorporate year dummies to account for systematic differences in given years having used the mediation analysis. ${ }^{7}$ Given the interest of the study is in determining the impact of a set of factors on V-C salaries we provide the second stage estimates here. The first panel examines a set of individual characteristics finding some substantial differences in how V-C personal characteristics relate to remuneration. ${ }^{8}$

\section{$<$ INSERT TABLE 2>}

Panel 2 examines a set of governance variables. It shows that V-C participation on remuneration panels does not appear to exhibit a direct impact on remuneration, however, the extent of disclosure has a well determined influence. The number of members on committees has a differential impact on each segment of the sector, with larger committees tempering remuneration in "new" institutions, but the opposite being the case in "old" institutions. 9

\footnotetext{
${ }^{6}$ Furthermore, we undertook formal analysis testing differences between the samples and confirmed (not surprisingly) that substantive and statistically significant differences between them.

${ }^{7}$ We tested whether there we statistical differences between the "old" and "new" institutions and found that there were thus validating our approach to the analysis. We also undertook sensitivity analysis excluding variable to check the stability of the results and found them robust.

${ }^{8}$ Other than being only of methodological relevance to the paper hence not being provided due to space considerations.

${ }^{9} \mathrm{We}$ also examined changes in salary and found qualitatively identical results with respect to the governance variables.
} 
Panel 3 suggests that performance does have effects which are quite intuitive. In "new" less-research intensive institutions, total income is positively correlated with remuneration, as is 'impactful' research - however measures of teaching quality (NSS) and quantity (number of students) are not. In older universities, traditional measures of research matter more.

Finally, year and regional effects are jointly significant controls with F-tests of more than $35 .^{10}$

\section{DISCUSSION AND CONCLUSION}

Our findings corroborate the notion that remuneration committees have a limited impact on executive pay. We do not find any evidence to support the first hypothesis, i.e. that V-Cs are paid more if they sit on the university's pay committee. However, we do find some evidence that the size of the committee matters, as proposed in the second hypothesis. An explanation of the lack of support for the first hypothesis might be that the direct influence of V-Cs with a seat on the remuneration committee on their own pay is partially offset by what is likely to be a stronger engagement with pay issues, as well as possibly a greater sensitivity towards the consequences of high pay awards. Our results for the second hypothesis indicate that both larger and smaller remuneration committees may temper V-C salaries, at "new" and "old" universities respectively. While a larger committee is likely to dilute the influence of powerful individuals, thus making it more difficult for V-Cs to dominate proceedings if they sit on the committee, when systemic checks and balances are weaker (Kent et al., forthcoming), smaller committees are likely to have a higher concentration of expertise and may therefore work more effectively towards a fair pay structure, when check and balances are stronger. Our findings show that the former logic, which aligns with our hypothesis, is

\footnotetext{
${ }^{10}$ We also experiment with OLS estimation which while less efficient does have the advantage of enabling us to obtain $\mathrm{R}^{2}$ which were a respectable $51.1 \%$ for the "new" and $66.6 \%$ of the "old" universities.
} 
more applicable at "new" institutions, whereas the latter rationale may explain the outcome at "old" universities. Higher levels of disclosure, measured by the publication of committee meeting minutes, is associated with higher V-C pay, as predicted by our third hypothesis. This finding is broadly in line with the notion that disclosure is a two-edged sword with costs and benefits (c.f. Hermalin and Weisbach, 2012).

We find modest evidence that institutional performance is related to V-C pay; this would confirm earlier work which suggests that under specific circumstances, material rewards can impact on senior manager performance (Shaw and Gupta, 2015). The finding that different performance metrics are associated with V-C pay levels at different types of institutions is broadly in line with our fourth hypothesis. However, we found that it was only in "old" institutions that rankings with respect to research outputs were influential, while the REF impact was notably more influential in "new" institutions. That 'impact' is more rewarded in "new" institutions may be reasonable, as it may be difficult for new institutions to be able to compete with respect to scholarly outputs, whereas there are clear benefits of being able to show a social and economic impact in the local economy and beyond: however, impact may be difficult to evidence, allowing more opportunities to game the system. There was no identifiable relation between the key teaching quality measure the NSS. In other words, 'old' universities are more focused rewarding research publication performance and 'new' ones perceived impact, but neither do much in terms of two key measures of teaching performance, a particularly surprising finding in the case of teaching intensive institutions. Finally, we find evidence that the financial success of the institution was well determined only in "new" institutions, perhaps owing to their more fragile financial base.

Through a systematic marketization of the HE sector and by encouraging an increasingly metric-driven approach to university leadership, policy-makers have created an environment where V-Cs have opportunities to behave as value-maximizing agents. Second, 
we find some evidence to indicate that $\mathrm{V}-\mathrm{Cs}$ act in line with the managerial power approach (Bebchuk and Fried 2003; Boyle and Roberts, 2013), suggesting that V-Cs will use their internal power within organisations to extract a disproportionate amount of the value created by the institution; this problem seems one most pronounced in 'new' universities. We found that disclosure was positively related to pay: ironically this would suggest that calls for greater transparency in VC pay setting may drive pay even higher.

Does this mean that there is a case for stronger regulation of universities? It may be that other broader socio-economic factors are at play that are not easily identified empirically. Council members encompass individuals in senior leadership roles, whose pay has risen precipitously over recent decades. Such individuals, who are well aware of the greater flow of revenues and growth in what is a highly successful sector, may be particularly inclined to reward university leaders for the growing complexity of their role. Thus, many of the classical arguments for CEO pay increases in the private sector are likely to play out similarly in academia (Cornell, 2004). In short, VC pay seems to represent an inevitable by-product of the adoption of practices from the private sector; in this case, further marketization of the HE sector would make the problem worse, not better. Again, the dominant effects of government regulatory changes to date has been to weaken the powers of key stakeholders (local communities and academics), and centralise it in the hands of university managers (Shattock 2017); yet, it is when the power of VCs is constrained that pay is better aligned to performance. Finally, constant regulatory tinkering clearly makes the job much more difficult, and hence, may justify even higher pay. The academic influence of the V-C (indicated by their life-time citations) as a determinant of salary only in the "new" universities. This may reflect higher levels of academic influence being a scarce commodity in the new university sector. On the other hand, research-intensive institutions may have less 
need to shore up their credibility based on their V-C's own research reputation; it also makes the distinction between the $\mathrm{VC}$ and the rank and file professoriate less pronounced.

Students are the most transitory members of a university community and a focus on their concerns may, at the least, open issues of continuity; however, of all the reward metrics, teaching quality appears to be the least influential. This article does not explore what would happen if association members - that is, students and staff - genuinely ran universities. Again, the choice of performance metrics is likely to vary greatly according to the relative representation of association members. Finally, at a theoretical level, there are clear limitations in the application of agency theory to universities; there remains a lack of clarity as to who the principals really are (are they simply association members?), and it is difficult to reach conclusions as to the scale of any agency problems given this. This would suggest that alternative approaches for understanding universities and how they are governed, either as 'republics of science' who have, over centuries, developed viable and sustainable governance models (Polanyi, 2000) and/or simply a social good that deserves sustaining whatever its imperfections (Oakeshott, 2004). We also encountered much heterogeneity in the sector, most notably in terms of the divide between "new" and "old" institutions; the latter have more robust internal governance structures. If the core function of the university is research and teaching, then some are much better at incentivising VCs this than others. This diversity would indicate that universities are indeed capable of devising internal governance solutions. At the same time, the modest and uneven linkages between pay and performance would indicate the basis of a case for pay restraint.

\section{Limitations and future research}

Our study is based on a survey of academics in a single country and this is an important limitation to the generalizability of our findings. However, the UK has been at the forefront of developing research assessment systems, and it has sought to institutionalize their 
assessment on a recurring cycle, for example incorporating impact in its latest round (Hicks 2012); it has also developed a system for grading teaching quality, the Teaching Excellence Framework. As such, UK institutions are perhaps 'canaries in the mine' for academics in other contexts where such assessment systems are being put in place.

A performance pay approach assumes that performance can indeed be measured. A central theme of the industrial relations literature is that this can never fully be so, and that attempts to measure it may have perverse consequences (c.f. Hyman, 2018). We have used a series of measures relevant to the UK universities context' however each has its own set of limitations and has been criticised in the literature. For example, York (2009) points to limitations in the NSS, while Bell and Brooks (2017) also point to methodological issues with the measure. We cannot conclude that the lack of influence of teaching metrics means that universities do not take teaching seriously; rather, it could be that this reflects the challenges of accurately measuring teaching quality and/or the lack of legitimacy externally imposed metrics have within the sector. Indeed, policy makers considering the development of further performance metrics to judge universities by would be well advised to reflect further on this question. There is a substantive literature highlighting the limits of both peer review and citation-based metrics. Thus, even if UK universities have become more corporatist in their objectives it does not necessarily mean that finding a limited relationship between pay and performance of $\mathrm{V}-\mathrm{C}$ is inherently bad; taking account of a wider range of measures might indicate a better - or worse - alignment between performance and pay.

Tosi and Gomez-Mejia (1989) argue that, within owner controlled firms, pay is much better aligned to performance than in managerially controlled ones. It could be argued that the misalignment between $\mathrm{V}-\mathrm{C}$ pay and performance indeed reflects a product of excessive managerial power, rather than owner control. However, this raises the question as to who really owns universities. If one returns to their role as voluntary associations, then this would 
be defined as their transient memberships (Moodie and Eustace 2011). Although this could be contested, the alternatives would be council members or government. Although councils may have a formal role as supreme governing bodies, members generally lack de facto, if not de jure accountability. Meanwhile, constant shifts in UK government higher education policy would suggest the elusiveness of sustainable regulatory fixes.

\section{References}

Ackers, P. (2016), 'Free collective bargaining and incomes policy: learning from Barbara Wootton and Hugh Clegg on post-war British Industrial Relations and wage inequality', Industrial Relations Journal, 47 (5-6), 434-453.

Allegrini, M and Greco, G (2013), 'Corporate boards, audit committees and voluntary disclosure: Evidence from Italian listed companies', Journal of Management \& Governance, $17,187-216$.

Bachan, R. and B. Reilly (2017), Pay in education: Vice Chancellor and Rector Remuneration, In Johnes et al Eds, Handbook of Contemporary Education Economics, Edward Elgar.

Bebchuk, LA and Fried, JM (2003), 'Executive compensation as an agency problem', The Journal of Economic Perspectives, 17, 71-92.

Berdahl, R (1990) 'Academic freedom, autonomy and accountability in British universities', Studies in Higher Education, 15(2): 169-180.

Bhagat, S and Black, B (1999), 'The uncertain relationship between board composition and firm performance. The Business Lawyer, 921-963.

Boselie, P., Dietz, G. and Boon, C. (2005) Commonalities and contradictions in HRM and performance research', Human Resource Management Journal, 15(3): 67-94.

Boyle, G and H Roberts (2013) 'CEO presence on the compensation committee: a puzzle', Journal of Economics and Business, 70: 16-26

Breakwell, GM and MY Tytherleigh (2010), 'University leaders and university performance in the United Kingdom: is it 'who' leads, or 'where' they lead that matters most?', Higher Education 60, 491-506.

Brooks, C, Bell, A (2017) What makes students satisfied? A discussion and analysis of the UK's national student survey, Journal of Further and Higher Education, 42(8), 1118-1142

Conyon, MJ Peck, SI (1998), 'Board control, remuneration committees, and top management compensation', Academy of Management Journal, 41, 146-157. 
Cornell, B (2004) 'Compensation and recruiting: private universities versus private corporations', Journal of Corporate Finance, 10, 37-52.

Daily Mail (2017a) University Fees are Mis-Selling Scandal Says Lawson. Daily Mail 7 December 2017. www.dailymail.co.uk/wires/.../Students-plugging-research-funding-gaptuition-fees.html (accessed 7 December 2017)

Daily Mail (2017b) Universities Gave Vice Chancellors Pay Rise of 13\% Last Year. Daily Mail 15 June 2017. www.dailymail.co.uk/news/article.../University-fat-cat-pay-soars-studentnumbers-fall.html (accessed 7 December 2017)

Deem, R., Hillyard, S., Reid, M. (2007) Knowledge, higher education and the new managerialism. Oxford, England: Oxford University Press.

Edwards, P. (2015), 'Industrial relations, critical social science and reform: I, principles of engagement', Industrial Relations Journal, 46 (3), 173-186.

Essaji, A and Horton, S (2010), 'Silent escalation: salaries of senior university administrators in Ontario, 1996-2006', Higher Education, 59(3), 303-322.

Ezzamel, M and Watson, R (1998), 'Market comparison earnings and the bidding-up of executive cash compensation: Evidence from the United Kingdom', Academy of Management Journal, 41, 221-231.

Gregory-Smith, I (2012), 'Chief executive pay and remuneration committee independence', Oxford Bulletin of Economics and Statistics, 74, 510-531.

Guardian (7/09/2017), Minister to threaten universities with fines for excessive salaries.

Guest, D.E. (2011). 'Human resource management and performance: still searching for some answers', Human Resource Management Journal, 21(1), 3-13.

Hogan, J (2011), 'Is higher education spending more on administration and, if so why?', Perspectives: Policy and Practice in Higher Education, 15, 7-13.

Hogan, J (2012) Restructuring revisited. Changing academic structures in UK universities. Perspectives: Policy and Practice in Higher Education, 16, 129-135.

Holmström, B and P Milgrom (1991), Multitask principal-agent analyses: Incentive contracts, asset ownership, and job design', The Journal of Law, Economics, and

Organization, 7(1), 24-52.

Hermalin, BE and Weisbach, MS, (2012), Information disclosure and corporate governance. The Journal of Finance, 67, 195-233.

Hicks, D (2012). 'Performance-based university research funding systems', Research Policy 41, 251-261.

Hyman, R. (2018). 'What future for industrial relations in Europe?', Employee

Relations, 40(4), 569-579. 
ITV (2017) Salaries of high-paid Vice-Chancellers to be monitored by new regulator. (accessed 7 September 2017)

Kanapathippillai, S, Mihret, D, and Johl, S (2017) Remuneration Committees and Attribution Disclosures on Remuneration Decisions: Australian Evidence. Journal of Business Ethics, https://link.springer.com/article/10.1007/s10551-017-3736-7.

Kent, P, Kercher, K and Routledge, J (2016) Remuneration committees, shareholder dissent on CEO pay and the CEO pay-performance link. Accounting \& Finance, http://onlinelibrary.wiley.com/doi/10.1111/acfi.12222/abstract

Lancaster, T (2000), 'The incidental paratmeter problem since 1948', Journal of Econometrics, 95, 391-413.

Lee, FS (2006), 'The Research Assessment Exercise, the state and the dominance of mainstream economics in British universities', Cambridge Journal of Economics, 31(2), 309325.

Martin, BR (2011), 'The Research Excellence Framework and the 'impact agenda': are we creating a Frankenstein monster?', Research Evaluation 20: 247-254.

Moodie, G and Eustace, R (2011) Power and authority in British universities. Abingdon: Routledge.

Oakeshott, M (2004), 'The idea of a university', Academic Questions, 17(1), 23-30.

Oswald, A (2017) V-C pay: Are vice-chancellors worth their salaries? Times Higher Education, 14 September 2017.

Perkmann, M, Tartari, V, McKelvey, M, Autio, E, Broström, A, D’Este, P, Fini, R, Geuna, A, Grimaldi, R, Hughes, A (2013), 'Academic engagement and commercialisation: A review of the literature on university-industry relations', Research Policy 42: 423-442.

Polanyi, M (2000), 'The republic of science: Its political and economic theory', Minerva 38, $1-21$.

Shattock, M. (2017). 'University governance in flux. The impact of external and internal pressures on the distribution of authority within British universities: A synoptic view', Higher Education Quarterly, 71(4), 384-395.

Stockhammer, E. (2017), 'Determinants of the wage share: a panel analysis of advanced and developing economies', British Journal of Industrial Relations, 55(1), 3-33.

Ross, J (2019), 'Putting Australian V-C pay into perspective: The stratospheric sums pocketed by university bosses make little sense, but nothing about salaries makes much sense' Times Higher Education, 29 May 2019.

Shaw, JD and Gupta, N (2015), 'Let the evidence speak again! Financial incentives are more effective than we thought', Human Resource Management Journal, 25(3), 281-293. 
Stone, J (2017), University vice chancellor justifies quarter-of-a-million pound salary amid claims of bloated management layer. The Independent 14 July 2017. Available at: http://www.independent.co.uk/news/uk/politics/university-vice-chancellors-salaries-tuitionfees-a7840401.html

Tarbert, H, K Tee and R Watson (2008), 'The legitimacy of pay and performance comparisons: an analysis of UK university chancellors pay awards', British Journal of Industrial Relations, 46(4), 771-805.

Times Higher Education Supplement (2017a) The Jo Johnson Definition of a University. 08 May 2017. https://www.timeshighereducation.com/blog/jo-johnson-definition-university

Times Higher Education Supplement (2017b) Jo Johnson: Grade Inflation Ripping Through Sector. 07 September 2017. https://www.timeshighereducation.com/search?search=jo\%20johnson

Tosi Jr, HL and Gomez-Mejia, LR (1989), 'The decoupling of CEO pay and performance: An agency theory perspective', Administrative Science Quarterly, 34(2), 169-189.

Woodall, T, Hiller, A and Resnick, S (2014), 'Making sense of higher education: students as consumers and the value of the university experience', Studies in Higher Education, 39(1), 48-67.

Table 1. Summary statistics including pairwise correlations with the dependent variable 


\begin{tabular}{|c|c|c|c|c|c|}
\hline Variable Name & & $\begin{array}{l}\text { "New" } \\
\text { universities }\end{array}$ & $\begin{array}{l}\text { Pairwise Correlations } \\
\text { (Dependent Variable) }\end{array}$ & $\begin{array}{l}\text { "Old" } \\
\text { universities }\end{array}$ & $\begin{array}{l}\text { Pairwise Correlations } \\
\text { (Dependent Variable) }\end{array}$ \\
\hline Salary (excluding pension) & & 241,342 & & 298,256 & \\
\hline \multicolumn{6}{|l|}{ Individual Characteristics } \\
\hline Gender $($ Male $=1)$ & & 0.81 & $0.23 *$ & 0.81 & $-0.14 *$ \\
\hline Age at appointment & & 57.81 & 0.03 & 60.74 & $0.22 *$ \\
\hline Tenure & & 6.56 & $0.12 *$ & 6.39 & 0.01 \\
\hline Tenure (Squared) & & 43.03 & $0.11 *$ & 40.78 & $0.26 *$ \\
\hline \multicolumn{6}{|l|}{ Academic Influence (life } \\
\hline \multirow[t]{2}{*}{ Title } & Knighthood & 0.06 & $0.10 *$ & 0.23 & $0.22 *$ \\
\hline & Public Honours & 0.35 & $0.14 *$ & 0.22 & 0.01 \\
\hline Previous occupation & $\mathrm{VC}$ & 0.38 & -0.09 & 0.37 & 0.09 \\
\hline \multirow[t]{3}{*}{ (role) } & Deputy VC & 0.35 & 0.03 & 0.25 & $-0.21 *$ \\
\hline & Other HE & 0.12 & $0.13 *$ & 0.32 & $0.06 *$ \\
\hline & Other & 0.15 & -0.03 & 0.05 & 0.08 \\
\hline \multirow{4}{*}{$\begin{array}{l}\text { Previous occupation } \\
\text { (sector) }\end{array}$} & Public & 0.12 & 0.06 & 0.10 & -0.01 \\
\hline & Private & 0.04 & 0.09 & 0.01 & 0.16 \\
\hline & $\mathrm{HE}$ & 0.77 & $-0.18 *$ & 0.75 & -0.04 \\
\hline & Private and $\mathrm{HE}$ & 0.06 & $0.15 *$ & 0.14 & 0.02 \\
\hline Born in & UK & 0.87 & -0.02 & 0.79 & -0.04 \\
\hline Hired from & UK & 0.94 & -0.05 & 0.85 & -0.15 \\
\hline \multirow[t]{3}{*}{ Academic Background } & Science & 0.35 & 0.06 & 0.61 & 0.08 \\
\hline & Social Science & 0.10 & 0.09 & 0.23 & -0.12 \\
\hline & Arts and Humanities & 0.49 & $-0.18 *$ & 0.16 & 0.02 \\
\hline Oxbridge (UG or PG) & & 0.22 & $0.11 *$ & 0.38 & -0.05 \\
\hline Acting VC & & 0.03 & $-0.35 *$ & 0.04 & $-0.16 *$ \\
\hline Internal Candidate & & 0.21 & -0.09 & 0.18 & -0.11 \\
\hline Entrant & & 0.12 & $-0.11 *$ & 0.16 & -0.10 \\
\hline \multicolumn{6}{|c|}{ Governance (Remuneration Committee) } \\
\hline & VC on committee & 0.57 & $0.12 *$ & 0.82 & 0.03 \\
\hline & No. of members & 5.64 & $-0.08 *$ & 6.48 & 0.08 \\
\hline & No Minutes & 0.43 & $-0.02 *$ & 0.50 & 0.00 \\
\hline & Provide Minutes (with retracations) & 0.38 & $-0.08 *$ & -0.03 & 0.05 \\
\hline & Provide Minutes (no retractions) & 0.31 & $-0.02 *$ & 0.16 & $0.06 *$ \\
\hline & Average Faculty Salary & 47,192 & 0.03 & 49,456 & 0.10 \\
\hline \multicolumn{6}{|c|}{ Performance Characteristics (t-1) } \\
\hline Overall & Total Income & 156,404 & $0.28 *$ & 420,421 & $0.21 *$ \\
\hline \multirow[t]{6}{*}{ Research } & Total Citations & 20.8 & $0.20 *$ & 56.0 & $0.13 *$ \\
\hline & Funding Body Grants & 69,990 & $0.20 *$ & 140,349 & $0.23 *$ \\
\hline & REF Outputs (GPA) & 94.63 & $-0.23 *$ & 36.16 & $-0.15 *$ \\
\hline & REF Impact & 78.43 & $-0.24 *$ & 33.43 & $-0.11 *$ \\
\hline & Change between RAE2008 \& & & & & \\
\hline & REF2014 & -1.62 & $-0.01 *$ & 0.81 & $0.22 *$ \\
\hline \multirow[t]{4}{*}{ Teaching } & NSS & 85.18 & 0.06 & 88.35 & -0.08 \\
\hline & No. Non-UK Postgraduate students & 3,518 & $0.20 *$ & 4,656 & $0.28 *$ \\
\hline & No. Non-UK Undergraduate student & 719 & $0.25 *$ & 2,085 & 0.41 \\
\hline & Tuition fees income & 52,004 & $0.28 *$ & 95,126 & $0.34 *$ \\
\hline \multicolumn{6}{|l|}{ Other } \\
\hline Insitutional complexity & No. of Staff (FTE) & 2,298 & $0.30 *$ & 4,860 & $0.26 *$ \\
\hline Administrative burden & Academic to administative staff ratic & 2.02 & $0.12 *$ & 1.95 & -0.04 \\
\hline $\mathrm{N}$ & & 365 & & 146 & \\
\hline
\end{tabular}


Table 2. Determinants of (log)salary (Estimated using GLS)

\begin{tabular}{|c|c|c|c|c|c|}
\hline \multirow[t]{2}{*}{ Variable Name } & \multirow[t]{2}{*}{ Measurement } & \multicolumn{2}{|c|}{ "New" universities } & \multicolumn{2}{|c|}{ "Old" universities } \\
\hline & & Coeff & z-stat & Coeff & z-stat \\
\hline \multicolumn{6}{|l|}{$\begin{array}{l}\text { Individual Characteristics } \\
\end{array}$} \\
\hline Gender & Gender $($ Male $=1)$ & -0.014 & $(0.25)$ & $-0.251 * *$ & $(2.28)$ \\
\hline Age at appointment & Years & -0.002 & $(0.36)$ & 0.001 & $(0.84)$ \\
\hline Tenure & & $0.044 * *$ & $(2.37)$ & $0.104 *$ & $(1.82)$ \\
\hline Tenure (Squared) & & -0.002 & $(1.58)$ & -0.005 & $(1.62)$ \\
\hline Academic Influence (000s) & & $0.032 * * *$ & $(3.07)$ & $0.006 * * *$ & $(2.89)$ \\
\hline \multirow[t]{2}{*}{ Titular Status } & Knighthood & 0.059 & $(0.78)$ & -0.048 & $(0.38)$ \\
\hline & Public Honours & 0.055 & $(1.38)$ & 0.045 & $(0.41)$ \\
\hline Previous occupation & Deputy VC & $0.119 * *$ & $(2.01)$ & -0.178 & $(1.44)$ \\
\hline \multirow[t]{2}{*}{ (role) -Ref. VC } & Other HE & 0.184 & $(1.44)$ & 0.041 & $(0.33)$ \\
\hline & Other & 0.021 & $(0.14)$ & 0.100 & $(0.59)$ \\
\hline Previous occupation & Public & -0.022 & $(0.18)$ & 0.037 & $(0.23)$ \\
\hline (sector) & Private & -0.148 & $(1.24)$ & 0.157 & $(1.27)$ \\
\hline Ref. HE & Private and $\mathrm{HE}$ & -0.016 & $(0.19)$ & -0.197 & $(1.44)$ \\
\hline Born in & Ref. UK & -0.015 & $(0.26)$ & 0.153 & $(1.38)$ \\
\hline Hired from & Ref. UK & $0.175 *$ & $(1.64)$ & -0.262 & $(1.38)$ \\
\hline Academic Background & Social Science & $-0.239 * *$ & $(2.39)$ & -0.137 & $(1.60)$ \\
\hline \multirow[t]{2}{*}{ Ref. Science } & Arts and Humanities & -0.058 & $(0.42)$ & $-0.203 *$ & $(1.70)$ \\
\hline & Other & -0.131 & $(1.39)$ & 0.000 & \\
\hline Oxbridge (UG or PG) & & 0.000 & $(0.33)$ & $-0.037 * *$ & $(1.98)$ \\
\hline Acting VC & & -0.403 & $(1.10)$ & -0.603 & $(1.24)$ \\
\hline Internal Candidate & & -0.050 & $(1.23)$ & 0.059 & $(0.44)$ \\
\hline Entrant & & -0.070 & $(0.91)$ & 0.000 & $(1.34)$ \\
\hline Governance & VC on committee & 0.042 & $(1.20)$ & 0.208 & $(1.35)$ \\
\hline \multirow[t]{3}{*}{ (Ref. No minute provided) } & Provide Minutes (with redacations) & $0.065 * * *$ & $(3.29)$ & $0.166 *$ & $(1.86)$ \\
\hline & Provide Minutes (no redractions) & $0.109 * *$ & $(2.17)$ & $0.170 * *$ & $(2.33)$ \\
\hline & No. of members & $-0.084 * *$ & $(2.47)$ & -0.053 & $(1.56)$ \\
\hline Relative salary & Average Faculty Salary & 0.002 & $(0.97)$ & -0.003 & $(0.08)$ \\
\hline Overall & Income (mn) & $0.142 * * *$ & $(2.60)$ & -0.073 & $(0.51)$ \\
\hline \multirow[t]{5}{*}{ Research } & Total Citations (000s) & 0.038 & $(0.36)$ & $0.001 *$ & $(1.77)$ \\
\hline & Research grants (000s) & $0.003 * * *$ & $(3.43)$ & $0.001 *$ & $(1.70)$ \\
\hline & Change between RAE2008 and REF2014 & -0.001 & $(0.44)$ & $0.001 *$ & $(1.78)$ \\
\hline & RAE/REF Outputs & 0.001 & $(1.49)$ & $0.007 * *$ & $(2.22)$ \\
\hline & REF Impact & -0.002 & $(1.65)$ & $-0.002 * * *$ & $(2.54)$ \\
\hline \multirow[t]{5}{*}{ Teaching } & NSS & 0.003 & $(0.40)$ & 0.007 & (1.13) \\
\hline & TEF & 0.056 & $(1.99)$ & -0.081 & $(1.35)$ \\
\hline & No. Non-UK Postgraduate students (000s) & 0.001 & $(1.03)$ & 0.000 & $(0.21)$ \\
\hline & No. Non-UK Undergraduate students (000s & 0.000 & $(0.97)$ & 0.005 & $(0.17)$ \\
\hline & Tuition fees income (mn) & $0.315 * * *$ & $(3.31)$ & 0.464 & $(0.96)$ \\
\hline \multirow[t]{2}{*}{ Insitutional complexity } & No. of Staff (FTE, 000s) & 0.035 & $(0.77)$ & 0.012 & $(0.60)$ \\
\hline & Ratio of Academic Staff to Administative & & & & \\
\hline \multirow[t]{2}{*}{ Administrative burden } & Staff & $0.066 * * *$ & $(2.77)$ & 0.034 & $(0.32)$ \\
\hline & Constant & $12.214 * * *$ & (13.86) & $12.877 * * *$ & $(11.37)$ \\
\hline Area & & YES & & YES & \\
\hline Year & & YES & & YES & \\
\hline $\mathrm{N}$ & & 365 & & 146 & \\
\hline Log pseudolikelihood & & -25.39 & & 36.31 & \\
\hline
\end{tabular}

Notes: The GLS estimations assume a Gaussian (normal) distribution. White adjusted standard errors. 